\title{
Effect of plant-growth-promoting rhizobacteria inoculation on plant growth, productivity and economics of Basmati rice
}

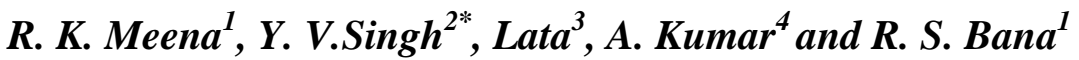 \\ ${ }^{1}$ Division of Agronomy, ${ }^{2}$ National Centre for Blue-Green Algae, ${ }^{3}$ Division of Microbiology, ${ }^{4}$ IASRI \\ Indian Agricultural Research Institute, New Delhi -110 012, India
}

\begin{abstract}
A field experiment was conducted in a wet season (Kharif) to study the effects of plant growthpromoting rhizobacteria(PGPR) inoculation on agronomic traits and productivity of Basmati rice (cv. 'Pusa Basmati 1401') in a randomized block with twelve treatments. We evaluated one bacterial (Providencia sp. PW5) and one cyanobacterial strain (Anabaena sp. CR3), and also a Multani mitti (Fuller's earth)-based blue-green algal biofertilizer (a composite culture of Anabaena, Nostoc, Tolypothrix and Aulosira sp.). Plant growth, yield attributes, yield and net return of rice were significantly improved due to the rhizobacterial inoculation. The highest responses were recorded from combined inocula of bacteria and cyanobacteria together with compost.
\end{abstract}

Keywords: Bacterial inoculants, BGA, cyanobacterial inoculants, PGPR, yield attributes.

\section{Introduction}

Rice is the major staple crop of nearly half of the world's population, and is particularly important in Asia, where approximately $90 \%$ of world's rice is produced and consumed. Rice yields range from less than $1.0 \mathrm{t} \mathrm{ha}^{-1}$ under very poor rain-fed conditions to $10.0 \mathrm{t} \mathrm{ha}^{-1}$ in intensive temperate irrigated conditions (Zeigler \& Barclay 2008). Rice plants require large amounts of mineral nutrients including nitrogen for their growth, development and grain production, removing around $16-17 \mathrm{~kg} \mathrm{~N}$ for each ton of rough rice produced including straw (Sahrawat 2000). However, most of the rice soils of the world are deficient in $\mathrm{N}$, so nitrogenous fertilizer applications (usually urea) are required to meet the $\mathrm{N}$ demand. However, the efficiency of added urea-N is very low, often only $30-40 \%$ and in some cases even lower (Choudhury \& Khanif 2001). This low N-use efficiency is mainly due to denitrification, $\mathrm{NH}_{3}$ volatilization and leaching losses (De Datta \& Buresh 1989). $\mathrm{NH}_{3}$ volatilization and denitrification cause atmospheric pollution, a problem of great concern to soil and environmental scientists around the world, so alternative sources of $\mathrm{N}$ should be applied to minimize such problems. Organic nutrient sources are important components of the nutrient cycle in agro-ecosystems, and could be utilized along with chemical fertilizers. Integrated nutrient management practices that rely primarily on judicious use of organic and inorganic sources have drawn the attention of rice scientists and farming communities.

Biological $\mathrm{N}$ fixation can play an important role in substituting for commercially available $\mathrm{N}$ fertilizer use in rice culture, thus reducing environmental problems to some extent. The use of biofertilizers can prevent the depletion of the soil organic matter (Jeyabal \& Kuppuswamy 2001). Wetland rice fields can provide ideal conditions for the growth of cyanobacteria, which accumulate $19-28 \mathrm{~kg} \mathrm{~N}^{-1}$ of crop, and can reduce the use of urea fertilizer in rice culture by $25-35 \%$ (Hashem 2001).

Bacterial inoculant biofertilizers are efficient sources of $\mathrm{N}$ used to substitute for urea- $\mathrm{N}$ in rice production. Some bacteria such as Azotobacter, Clostridium, Azospirillum, Herbaspirillum and Burkholderia can supplement urea-N via nitrogen fixation, while Rhizobium does the same by promoting the growth physiology or root morphology of the rice plant. In addition, by acting as rhizobacteria, they can improve the ability of the rice plant to assimilate soil $\mathrm{N}$, as well as being directly involved in increased uptake of nitrogen, synthesis

* Author for correspondence: email : yvsingh63@yahoo.co.in 
of phyto-hormones, solubilization of minerals such as phosphorus, and production of siderophores that chelate iron and make it available to the plant root (Bowen \& Rovira 1999). There is very little information regarding the use of plant growth-promoting rhizobacteria as biofertilizers, especially in rice, and therefore the present study was undertaken to investigate the effect of bacterial and cyanobacterial rhizobacteria and blue-green algae as components of integrated nitrogen management on the growth, yield and economics of rice production.

\section{Materials \& Methods}

The experiment was conducted during the rainy (Kharif) season (June-November) of 2011 at the research farm of the Indian Agricultural Research Institute, New Delhi, India $\left(28^{\circ} 40^{\prime} \mathrm{N}, 77^{\circ} 12^{\prime} \mathrm{E}\right.$, altitude $\left.228.6 \mathrm{~m}\right)$. The mean annual rainfall of Delhi is $650 \mathrm{~mm}$, with more than $80 \%$ generally occurring during the south-west monsoon season (July-September); mean annual evaporation is $850 \mathrm{~mm}$. During June to October, the maximum and minimum temperatures ranged between 43.6 (8 June) to $29.4{ }^{\circ} \mathrm{C}$ (30 Oct) and 11.9 (28 Oct) to $29{ }^{\circ} \mathrm{C}$ ( 7 June), respectively. The year 2011 had less than normal rainfall $(539.4 \mathrm{~mm}$ during June to October). The daily range of relative humidity was higher in June and October. The soils of the experimental field had $145.3 \mathrm{~kg} \mathrm{ha}^{-1}$ alkaline permanganate oxidizable N (Subbiah \& Asija 1956), $15.37 \mathrm{~kg} \mathrm{ha}^{-1}$ available $\mathrm{P}$ (Olsen et al. 1954), $254.2 \mathrm{~kg} 1 \mathrm{~N}$ ammonium acetate exchangeable K (Prasad et al. 2006) and 0.52\% organic carbon (Walkley \& Black 1934). The $\mathrm{pH}$ of the soil was 7.7 (1: 2.5 soil and water ratio).

The experiment was laid out in a randomized block design with twelve treatments, combinations of nitrogen (N), bacterial (BI:Providencia sp. strain PW5) and cyanobacterial (CI: Anabaena sp. strain CR3) inoculation, blue-green algae (BGA, as a Multani mitti [Fuller's earth]-based biofertilizer consisting of a composite culture of Anabaena, Nostoc, Tolypothrix and Aulosira sp.) and compost. BI, CI and BGA were applied at $1.5 \mathrm{~kg} \mathrm{ha}^{-1}$, while compost was applied at $5.0 \mathrm{t} \mathrm{ha}^{-1} .2 / 3 \mathrm{~N}$ was applied through urea and rest as per treatment.

The treatments were: $\mathrm{N}_{0}$ (no added $\left.\mathrm{N}\right) ; 2 / 3 \mathrm{~N}\left(80 \mathrm{~kg} \mathrm{ha}^{-1}\right.$ applied using urea; $\mathrm{N}_{120}(120 \mathrm{~kg}$ $\mathrm{ha}^{-1}$ applied using urea); $2 / 3 \mathrm{~N}+$ compost; $2 / 3 \mathrm{~N}+\mathrm{BI} ; 2 / 3 \mathrm{~N}+\mathrm{BI}+$ compost; $2 / 3 \mathrm{~N}+\mathrm{CI} ; 2 / 3 \mathrm{~N}+\mathrm{CI}+$ compost; $2 / 3 \mathrm{~N}+\mathrm{CI}+\mathrm{BI} ; 2 / 3 \mathrm{~N}+\mathrm{BI}+\mathrm{CI}+$ compost; $2 / 3 \mathrm{~N}+\mathrm{BGA}$ and $2 / 3 \mathrm{~N}+$ compost+ BGA.

The rice was a Basmati variety 'Pusa Basmati 1401'; treatments were replicated three

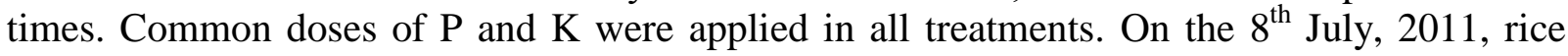
seedlings ( 21 days old) were transplanted out at $20 \mathrm{~cm} \times 10 \mathrm{~cm}$ spacing, keeping two seedlings per hill. Weeds were managed manually by two hand weeding at 25 and 45 days after transplanting. The crop was harvested in the first fortnight of October. The gross plot size was $5 \mathrm{~m} \times 3 \mathrm{~m}$ for each treatment.

Plant height was measured from the base of the plant at ground surface to the tip of the tallest leaf panicle. Numbers of tillers were noted by counting from the sampled unit. Dry matter accumulation was calculated from five hills taken from the sampling area and ovendried at $60 \pm 2^{\circ} \mathrm{C}$ : dry weight was calculated in $\mathrm{g} \mathrm{m}^{-2}$. Ten panicles were selected to measure panicle length and were also used to record total and mean panicle weight, and the number of grains panicle ${ }^{-1} .1000$ filled grains from the sampled panicles were counted by a seed counter and then weighed. After harvesting, threshing, cleaning and drying, the grain yield was recorded at $14 \%$ moisture. The straw yield was obtained by subtracting grain yield from the total biomass yield. Yields were expressed in $\mathrm{t} \mathrm{ha}^{-1}$. Gross and net returns were calculated based on the grain and straw yield and the prevailing market prices of labor, inputs and outputs (grain and straw) during the respective crop season. The benefit: cost ratio was calculated by dividing the net returns by the total cost of cultivation.

The data of the various parameters were analyzed using a randomized block ANOVA using SPSS-10. Treatment means were compared at a significance level of 0.05 . 


\section{Results}

Rice growth was significantly increased over the $\mathrm{N}$ control in the combined treatments $(\mathrm{CI}+\mathrm{BI}+$ compost and $\mathrm{BGA}+$ compost) (Table 1), with the highest values of the response variables being indistinguishable statistically from the recommended dose of $\mathrm{N}$ fertilizer $\left(\mathrm{N}_{120}\right)$. The treatment patterns varied with the response variable: in the case of dry matter accumulation there were no significant differences among any of the rhizobacterial treatments or $\mathrm{N}_{120}$ (see Table 1).

\begin{tabular}{|c|c|c|c|c|}
\hline Treatment & $\begin{array}{l}\text { Leaf Area } \\
\text { Index at } \\
60 \text { days }\end{array}$ & $\begin{array}{c}\text { Plant height (cm) } \\
\text { at harvest }\end{array}$ & $\begin{array}{l}\text { Number of } \\
\text { tillers } \mathrm{m}^{-2} \\
\text { at } \\
\text { harvest }\end{array}$ & $\begin{array}{l}\text { Dry matter } \\
\text { accumulation } \\
\left(\mathrm{g} \mathrm{m}^{-2}\right) \text { at } \\
\text { harvest }\end{array}$ \\
\hline $\mathrm{N}_{0}$ & $3.36^{\mathrm{d}}$ & $83.0^{\mathrm{e}}$ & $280.8^{\mathrm{d}}$ & $781.1^{\mathrm{c}}$ \\
\hline $2 / 3 \mathrm{~N}$ & $4.26^{\mathrm{c}}$ & $95.6^{\mathrm{d}}$ & $340.3^{c}$ & $972.3^{\mathrm{b}}$ \\
\hline $\mathrm{N}_{120}$ & $5.12^{\mathrm{ab}}$ & $109.9^{\mathrm{ab}}$ & $395.6^{\mathrm{ab}}$ & $1169.4^{\mathrm{a}}$ \\
\hline $2 / 3 \mathrm{~N}+$ compost & $4.60^{\mathrm{bac}}$ & $104.3^{\mathrm{c}}$ & $378.3^{\mathrm{ab}}$ & $1139.9^{\mathrm{a}}$ \\
\hline $2 / 3 N+B I$ & $4.42^{\mathrm{bc}}$ & $105.4^{\mathrm{bc}}$ & $387.5^{\mathrm{ab}}$ & $1141.3^{\mathrm{a}}$ \\
\hline $2 / 3 \mathrm{~N}+\mathrm{BI}+$ compost & $4.98^{\mathrm{abc}}$ & $106.7^{\mathrm{bc}}$ & $380.9^{\mathrm{ab}}$ & $1155.1^{\mathrm{a}}$ \\
\hline $2 / 3 \mathrm{~N}+\mathrm{CI}$ & $4.56^{\mathrm{bc}}$ & $104.8^{\mathrm{c}}$ & $369.1^{\mathrm{b}}$ & $1140.1^{\mathrm{a}}$ \\
\hline $2 / 3 \mathrm{~N}+\mathrm{CI}+$ compost & $5.01^{\mathrm{ab}}$ & $107.2^{\mathrm{bc}}$ & $380.5^{\mathrm{ab}}$ & $1156.5^{\mathrm{a}}$ \\
\hline $2 / 3 \mathrm{~N}+\mathrm{CI}+\mathrm{BI}$ & $4.73^{\mathrm{abc}}$ & $106.4^{\mathrm{bc}}$ & $373.8^{\mathrm{ab}}$ & $1147.2^{\mathrm{a}}$ \\
\hline $2 / 3 \mathrm{~N}+\mathrm{BI}+\mathrm{CI}+$ compost & $5.30^{\mathrm{a}}$ & $112.1^{\mathrm{a}}$ & $404.6^{\mathrm{a}}$ & $1175.4^{\mathrm{a}}$ \\
\hline $2 / 3 N+B G A$ & $4.79^{\mathrm{abc}}$ & $106.7^{\mathrm{bc}}$ & $372.9^{\mathrm{b}}$ & $1148.6^{\mathrm{a}}$ \\
\hline $2 / 3 \mathrm{~N}+$ compost $+\mathrm{BGA}$ & $4.99^{\mathrm{abc}}$ & $107.7^{\mathrm{bc}}$ & $381.4^{\mathrm{ab}}$ & $1157.9^{\mathrm{a}}$ \\
\hline se & 0.22 & 1.4 & 9.3 & 18.2 \\
\hline LSD (at $p=0.05$ ) & 0.65 & 4.1 & 27.3 & 53.4 \\
\hline
\end{tabular}

Table 1: The effect of plant-growth-promoting rhizobacteria on the mean values of different response variables in rice plants. See Methods for the meanings of the treatments. Means with the same superscript letter are not significantly different. Standard error of the mean (se) and the Least Significant Difference (LSD) are given.

\begin{tabular}{|c|c|c|c|c|c|c|}
\hline Treatment & $\begin{array}{l}\text { Effective } \\
\text { tillers } \mathbf{m}^{-2}\end{array}$ & $\begin{array}{c}\text { Panicle } \\
\text { length } \\
\text { (cm) }\end{array}$ & $\begin{array}{c}\text { Panicle } \\
\text { weight } \\
\text { (g) }\end{array}$ & $\begin{array}{l}\text { Number } \\
\text { of grains } \\
\text { panicle }^{-1}\end{array}$ & $\begin{array}{c}\text { Filled } \\
\text { grains } \\
\text { panicle }^{-1}\end{array}$ & $\begin{array}{c}\text { Test } \\
\text { weight } \\
\text { (g) }\end{array}$ \\
\hline $\mathrm{N}_{0}$ & $220.7^{\mathrm{d}}$ & $22.1^{\mathrm{e}}$ & $2.43^{\mathrm{d}}$ & $118.0^{\mathrm{d}}$ & $95.9^{\mathrm{d}}$ & $20.0^{b}$ \\
\hline $2 / 3 \mathrm{~N}$ & $291.7^{\mathrm{c}}$ & $26.8^{d}$ & $3.20^{\mathrm{c}}$ & $144.0^{\mathrm{c}}$ & $120.1^{\mathrm{c}}$ & $21.8^{\mathrm{ab}}$ \\
\hline $\mathrm{N}_{120}$ & $332.3^{\mathrm{b}}$ & $30.3^{\mathrm{ab}}$ & $3.66^{\mathrm{ab}}$ & $169.1^{\mathrm{ab}}$ & $148.8^{\mathrm{ab}}$ & $23.1^{\mathrm{a}}$ \\
\hline $2 / 3 \mathrm{~N}+$ compost & $316.1^{\mathrm{b}}$ & $27.5^{\mathrm{cd}}$ & $3.30^{\mathrm{bc}}$ & $154.2^{\mathrm{abc}}$ & $125.4^{\mathrm{c}}$ & $21.8^{\mathrm{ab}}$ \\
\hline $2 / 3 \mathrm{~N}+\mathrm{BI}$ & $309.8^{\mathrm{cb}}$ & $27.6^{\mathrm{cd}}$ & $3.29^{\mathrm{bc}}$ & $148.8^{\mathrm{bc}}$ & $126.5^{\mathrm{bc}}$ & $22.0^{\mathrm{a}}$ \\
\hline $2 / 3 \mathrm{~N}+\mathrm{BI}+$ compost & $322.3^{\mathrm{b}}$ & $29.3^{\mathrm{abc}}$ & $3.43^{\mathrm{abc}}$ & $159.8^{\mathrm{abc}}$ & $137.4^{\mathrm{abc}}$ & $22.3^{\mathrm{a}}$ \\
\hline $2 / 3 \mathrm{~N}+\mathrm{CI}$ & $320.8^{\mathrm{b}}$ & $26.7^{\mathrm{d}}$ & $3.35^{\mathrm{abc}}$ & $153.5^{\mathrm{abc}}$ & $129.0^{\mathrm{bc}}$ & $21.3^{\mathrm{ab}}$ \\
\hline $2 / 3 \mathrm{~N}+\mathrm{CI}+$ compost & $323.7^{\mathrm{b}}$ & $28.9^{\mathrm{abcd}}$ & $3.55^{\mathrm{abc}}$ & $169.3^{\mathrm{ab}}$ & $141.5^{\mathrm{abc}}$ & $21.8^{\mathrm{ab}}$ \\
\hline $2 / 3 \mathrm{~N}+\mathrm{CI}+\mathrm{BI}$ & $325.8^{\mathrm{b}}$ & $28.7^{\mathrm{abcd}}$ & $3.49^{\mathrm{abc}}$ & $163.5^{\mathrm{abc}}$ & $134.1^{\mathrm{abc}}$ & $22.4^{\mathrm{a}}$ \\
\hline $2 / 3 \mathrm{~N}+\mathrm{BI}+\mathrm{CI}+$ compost & $358.3^{\mathrm{a}}$ & $31.1^{\mathrm{a}}$ & $3.70^{\mathrm{a}}$ & $174.2^{\mathrm{a}}$ & $154.5^{\mathrm{a}}$ & $23.0^{\mathrm{a}}$ \\
\hline $2 / 3 N+B G A$ & $328.1^{\mathrm{b}}$ & $28.6^{\mathrm{bcd}}$ & $3.54^{\mathrm{abc}}$ & $155.5^{\mathrm{abc}}$ & $133.2^{\mathrm{abc}}$ & $21.1^{\mathrm{ab}}$ \\
\hline $2 / 3 \mathrm{~N}+$ compost+BGA & $331.0^{\mathrm{b}}$ & $29.1^{\mathrm{abcd}}$ & $3.65^{\mathrm{ab}}$ & $167.0^{\mathrm{ab}}$ & $138.8^{\mathrm{abc}}$ & $22.5^{\mathrm{a}}$ \\
\hline se & 7.8 & 0.7 & 0.12 & 6.8 & 6.7 & 0.6 \\
\hline LSD (at $p=0.05$ ) & 22.8 & 2.1 & 0.34 & 19.9 & 19.7 & 1.7 \\
\hline
\end{tabular}

Table 2: Effect of plant-growth-promoting rhizobacteria on yield attributes of Basmati rice. Abbreviations as in Table 1. 
Rhizobacterial inoculation also had a positive effect on yield attributes over the $\mathrm{N}_{0}$ control (Table 2). Again the maximum values were seen in the combined treatment (in this case $2 / 3 \mathrm{~N}+\mathrm{BI}+\mathrm{CI}+$ compost), statistically significant over the $\mathrm{N}_{0}$ and $2 / 3 \mathrm{~N}$ treatments and as high or even higher than the recommended fertilizer treatment $\left(\mathrm{N}_{120}\right)$ (see Table 2). Most of the yield attributes were superior with the application of combined rhizobacteria and also with blue-green algal biofertilizer with compost compared to single inocula.

Grain and straw yields significantly increased with rhizobacterial inoculation, bluegreen algae with compost or chemical $\mathrm{N}$ fertilizer over the $\mathrm{N}_{0}$ control (Table 3 ). Once more the highest grain and straw yields, and the highest harvest index, were obtained with the $2 / 3 \mathrm{~N}+\mathrm{BI}+$ $\mathrm{CI}+$ compost treatment, which was statistically indistinguishable from the $\mathrm{N}_{120}$ treatment. The response to combined inoculation of bacteria and cyanobacteria was better when with compost compared to without.

\begin{tabular}{|c|c|c|c|}
\hline Treatment & $\begin{array}{l}\text { Grain yield } \\
\qquad\left(t \text { ha }^{-1}\right)\end{array}$ & $\begin{array}{l}\text { Straw yield } \\
\left(\mathrm{t} \mathrm{ha}^{-1}\right)\end{array}$ & $\begin{array}{c}\text { Harvest index } \\
(\%)\end{array}$ \\
\hline $\mathrm{N}_{0}$ & $2.64^{\mathrm{f}}$ & $5.39^{\mathrm{e}}$ & $32.8^{\mathrm{c}}$ \\
\hline $2 / 3 \mathrm{~N}$ & $4.18^{\mathrm{e}}$ & $7.94^{\mathrm{d}}$ & $34.5^{\mathrm{abc}}$ \\
\hline $\mathrm{N}_{120}$ & $4.79^{\mathrm{ab}}$ & $8.71^{\mathrm{ab}}$ & $35.5^{\mathrm{ab}}$ \\
\hline $2 / 3 \mathrm{~N}+$ compost & $4.54^{\mathrm{bc}}$ & $8.34^{\text {bc }}$ & $35.3^{\mathrm{ab}}$ \\
\hline $2 / 3 \mathrm{~N}+\mathrm{BI}$ & $4.23^{\text {ed }}$ & $8.26^{\mathrm{cd}}$ & $33.9^{\mathrm{bc}}$ \\
\hline $2 / 3 \mathrm{~N}+\mathrm{BI}+$ compost & $4.66^{\mathrm{b}}$ & $8.62^{\mathrm{abc}}$ & $35.1^{\mathrm{ab}}$ \\
\hline $2 / 3 \mathrm{~N}+\mathrm{CI}$ & $4.35^{\text {cde }}$ & $8.42^{\mathrm{bc}}$ & $34.1^{\mathrm{bc}}$ \\
\hline $2 / 3 \mathrm{~N}+\mathrm{CI}+$ compost & $4.69^{\mathrm{b}}$ & $8.63^{\mathrm{abc}}$ & $35.2^{\mathrm{ab}}$ \\
\hline $2 / 3 \mathrm{~N}+\mathrm{CI}+\mathrm{BI}$ & $4.58^{\mathrm{bc}}$ & $8.56^{\mathrm{abc}}$ & $34.9^{\mathrm{ab}}$ \\
\hline $2 / 3 \mathrm{~N}+\mathrm{BI}+\mathrm{CI}+$ compost & $5.02^{\mathrm{a}}$ & $8.87^{\mathrm{a}}$ & $36.1^{\mathrm{a}}$ \\
\hline $2 / 3 \mathrm{~N}+\mathrm{BGA}$ & $4.53^{\mathrm{bcd}}$ & $8.57^{\mathrm{abc}}$ & $34.6^{\mathrm{abc}}$ \\
\hline $2 / 3 \mathrm{~N}+$ compost $+\mathrm{BGA}$ & $4.78^{\mathrm{ab}}$ & $8.65^{\mathrm{abc}}$ & $35.6^{\mathrm{ab}}$ \\
\hline se & 0.10 & 0.12 & 0.6 \\
\hline LSD (at p=0.05) & 0.28 & 0.36 & 1.6 \\
\hline
\end{tabular}

Table 3: Effect of plant-growth-promoting rhizobacteriaon grain and straw yield and harvest index of rice. Abbreviations as in Table 1.

Yield formation in cereals is a complex coordinated process that involves the build-up and subsequent re-assimilation of yield components. These processes are under genetic control and strongly affected by environmental conditions. This is shown by the high positive correlations between the various yield attributes and overall yield $\left(r^{2}\right.$ values varied between 0.70 and 0.96 ).

In terms of economics, the $2 / 3 \mathrm{~N}+\mathrm{BI}+\mathrm{CI}+$ compost treatment gave the highest net returns, while the recommended fertilizer (N120) gave 13.5\% less (Table 4). The $\mathrm{N}_{0}$ control treatment was substantially lower. Gross returns showed a similar pattern. The greatest benefit: cost ratio was obtained with the $2 / 3 \mathrm{~N}+\mathrm{BI}+\mathrm{CI}+$ compost treatment, where benefits were twice the costs (Table 4). 


\begin{tabular}{lcccc}
\hline \multicolumn{1}{c}{ Treatment } & $\begin{array}{c}\text { Gross } \\
\text { return }(\text { Rs } \\
\left.\text { ha }^{-1}\right)\end{array}$ & $\begin{array}{c}\text { Cost of } \\
\text { cultivation } \\
\left(\text { Rs ha }^{-1}\right)\end{array}$ & $\begin{array}{c}\text { Net return } \\
\left(\text { Rs ha }^{-1}\right)\end{array}$ & $\begin{array}{c}\text { B:C } \\
\text { ratio }\end{array}$ \\
\hline $\mathrm{N}_{0}$ & 63397 & 35295 & 28175 & 0.80 \\
$2 / 3 \mathrm{~N}$ & 99829 & 37179 & 62721 & 1.69 \\
$\mathrm{~N}_{120}$ & 114017 & 36675 & 68705 & 1.87 \\
2/3N+compost & 108290 & 39713 & 68507 & 1.73 \\
2/3N+BI & 101390 & 37269 & 64121 & 1.72 \\
2/3N+BI+compost & 111213 & 39805 & 67815 & 1.70 \\
2/3N+CI & 104117 & 37269 & 66848 & 1.79 \\
2/3N+CI+compost & 111740 & 39803 & 71937 & 1.81 \\
2/3N+CI+BI & 109320 & 37269 & 72051 & 1.93 \\
2/3N+BI+CI+compost & 119233 & 39805 & 79428 & 1.99 \\
2/3N+BGA & 108153 & 37269 & 70884 & 1.90 \\
2/3N+compost+BGA & 113810 & 39803 & 74007 & 1.86 \\
\hline
\end{tabular}

Table 4: Effect of different treatments on the economics of rice cultivation. Values per hectare are in Indian rupees (1 US\$ = 55 Rupees). Abbreviations as in Table 1.

\section{Discussion}

All the growth parameters, yield attributes, yield and net return of rice were significantly influenced by inoculation of plant-growth-promoting rhizobacteria, with the highest plant growth caused by the combined inoculation of bacteria and cyanobacteria together with compost and $80 \mathrm{~kg} \mathrm{~N} \mathrm{ha}^{-1}$. Ahmad et al. (2011) also found increases in plant growth parameters in rice due to the application of biofertilizers such as blue-green algae and Azolla. Sathiya \& Ramesh (2009) reported positive influences on growth parameters such as plant height, number of tillers and dry matter production of aerobic rice from different nitrogen management practices. The usefulness of increased $\mathrm{N}$ application on tiller production was observed by Singh \& Singh (2006). Similarly Pseudomonas fluorescens B16 isolated from the roots of graminaceous plants has been shown to colonize the roots of various plants, and to increase the height, flower number, fruit number and total fruit weight of tomato plants (Minorsky 2008).

The combined application of bacteria and cyanobacteria, blue-green algae with compost, and chemical $\mathrm{N}$ fertilizer significantly increased the number of effective tillers, panicle length, number of total grains per panicle, filled grains per panicleand test weight, over the control treatments $\left(\mathrm{N}_{0}\right.$ and $\left.2 / 3 \mathrm{~N}\right)$. Most of the yield attributes were superior with these treatments compared to single inoculation of bacteria and cyanobacteria. Chaudhary et al. (2010) found significant impact of rhizobacteria on yield attributes of rice - the number of panicles per hilland filled grains per hill. Biswas et al. (2000) reported that the yield increase of rhizobacteria-inoculated rice was due to significant increases in the number of panicles and the filled grains per panicle, and also the total number of spikelets per plant compared to control plants. Baghel (2011) reported increased plant attributes of rice due to the application of nitrogen by different sources. Ahmad et al. (2011) reported increased yield attributes such as the number of effective tillers, panicle length and number of grains per panicle in rice due to the application of biofertilizers such as blue-green algae and Azolla.

The grain and straw yields of rice increased significantly due to particular treatments. The highest grain yield was obtained with the combined treatment $(2 / 3 \mathrm{~N}+\mathrm{BI}+\mathrm{CI}+\mathrm{compost})$, followed by the recommended dose of $\mathrm{N}\left(120 \mathrm{~kg} \mathrm{ha}^{-1}\right)$ and other treatments having rhizobacteria and blue-green algae along with compost, especially in combination. The performance of blue-green algae significantly improved when applied with compost. 
Chaudhary (2008) did not find a significant increase in grain yield over control due to the single application of rhizobacteria such as Bacillus subtilis, but inoculation with Azospirillum brasilense increased yield over both control and Bacillus subtilis inoculation. He concluded that Azospirillum was more suitable for rice. Ahmad et al. (2011) found increased grain and straw yield of rice on application of biofertilizers such as blue-green algae and Azolla. Alam at al. (2001) also reported increased rice dry matter and yield, and concluded that yield increase was due to increased root length, leaf area and chlorophyll content. Tranvan et al. (2000) observed increases of 13 to $22 \%$ grain yield on application of growth-promoting rhizobacteria, and Mehnaz et al. (2007) concluded from a field trial that inoculation significantly increased grain yield by $11.7 \%$.

There are several possible mechanisms other than biological $\mathrm{N}_{2}$-fixation for the beneficial effects of bacteria on the growth of inoculated plants. One may be that the bacteria produce plant growth hormones such as gibberellic, indole-3-acetic acid, and cytokinin, which promote root growth (Barea \& Brown 1974). The high straw yield with rhizobacteria, bluegreen algae and compost could be attributed to the higher supply of $\mathrm{N}$ and other micronutrients in the soil (Bisht et al. 2006), and also the increased availability of Fe and other micronutrients (Nayyar \& Chhibba, 2000). Variation in the partitioning of photosynthates between the grain and the vegetative organs in different treatments possibly caused significant variation in the harvest index.

The combined application $(2 / 3 \mathrm{~N}+\mathrm{BI}+\mathrm{CI}+$ compost $)$ gave the highest net return and benefit: cost ratio. Ahmad et al. (2011) reported comparable net returns and benefit: cost ratios on application of biofertilizers. In our experiment the overall higher cost of compost influenced the cost of cultivation, and hence the returns and the benefit: cost ratio. However, the costs of the rhizobacteria and the blue-green algae were low, keeping the cost of cultivation low and thus increased the net return and gave a higher benefit: cost ratio.

\section{References}

Ahmad I, Singh YV, Shivay YS, Lata \& Pabbi S (2011) Relative response to inoculation of nitrogen-fixing and phosphate-solubilising micro-organisms on nutrient uptake of Basmati rice and soil properties. Pusa AgriScience 34: 34-40

Alam SM, Cui ZJ, Yamagishi T \&Ishii R (2001) Grain yield and related physiological characteristics of rice plants (Oryza sativa L.) inoculated with free-living rhizobacteria. Plant Production Science 4 (2): 126-130

Baghel JK(2011) Response of rice (Oryza sativa L.) varieties to integrated nitrogen management under aerobic conditions, Unpublished M. Sc thesis, Indian Agricultural Research Institute, New Delhi, India.

Barea JM \& Brown ME (1974) Effects on plant growth produced by Azotobacter paspali related to synthesis of plant growth regulating substances. Journal of Applied Bacteriology 37: 583-593

Bisht PS, Pandey PC \& Singh DK (2006) Effect of different sources of nutrients on rice (Oryza sativa L.) yield and soil nutrient status in rice-wheat cropping system. National Symposium on Conservation Agriculture and Environment, October 26-28, BHU, Varanasi, India

Biswas JC, Ladha JK, Dazzo FB, Yanni YG \& Rolfe BG (2000) Rhizobial inoculation influences seedling vigor and yield of rice. Agronomy Journal 92: 880-886

Bowen GD \& Rovira AD (1999) The rhizosphere and its management to improve plant growth. Advances in Agronomy 66: 1-102

Choudhary RL (2008) Performance of rice hybrids grown by system of rice intensification with plant growth promoting rhizobacteria. MSc thesis, Indian Agricultural Research Institute, New Delhi, India.

Choudhary RL, Kumar D, Shivay YS, Lata, Singh G \& Singh N (2010) Performance of rice (Oryza sativa) hybrids grown by the system of rice intensification with plant growth-promoting rhizobacteria. Indian Journal of Agricultural Sciences 78(11):917-920

Choudhury ATMA \& Khanif YM (2001) Evaluation of the effects of nitrogen and magnesium fertilization on rice yield and fertilizer nitrogen efficiency using $15 \mathrm{~N}$ tracer technique. Journal of Plant Nutrition 24: 855-871

De Datta SK \& Buresh RJ(1989) Integrated nitrogen management in irrigated rice. Advances in Soil Science 10:143-169

Hashem MA (2001) Problems and prospects of cyanobacterial biofertilizer for rice cultivation. Australian Journal of Plant Physiology 28: 881-888 
Jeyabal A \& Kuppuswamy G (2001) Recycling of organic wastes for the production of vermicompost and its response in rice legume cropping system and soil fertility. European Journal of Agronomy 15: 153-170

Mehnaz S, Weselowski B \& Lazarovits G (2007) Azospirillumcanadense sp. a nitrogen-fixing bacterium isolated from corn rhizosphere. International Journal of Systematic \& Evolutionary Microbiology 57: 620624

Minorsky PV (2008) On the inside. Plant Physiology 146: 323-324

Nayyar VK \& Chhiba IM (2000) Effect of green manuring on micronutrient availability in ricr-wheat cropping system of north-west India. In: long term soil fertility experiment in rice-wheat cropping system. Ricewheat consortium for the Indo-Gangetic plains, New Delhi, India, p. 68-72.

Olsen SR, Cole CV, Watanable FS \& Dean LA(1954) Estimation of available phosphorous in soils by extraction with sodium bicarbonate. U.S. Department of Agriculture Circular 939

Prasad R, Shivay YS, Kumar D \& Sharma SN (2006) Learning by Doing Exercises in Soil Fertility (A Practical Manual for Soil Fertility). Division of Agronomy, Indian Agricultural Research Institute, New Delhi, India: 68

Sahrawat KL(2000) Macro and micronutrients removed by upland and lowland rice cultivars in West Africa. Communications in Soil Science \& Plant Analysis 31: 717-72

Sathiya K \& Ramesh T (2009) Effect of split application of nitrogen on growth and yield of aerobic rice. Asian Journal of Experimental Sciences 23(1): 303-306

Singh YV \& Singh BV (2006) Role of cyanobacteria in scented rice farming. In: Mishra AK et al. (eds) Glimpses of cyanobacteria. Daya Publishing House, New Delhi, pp. 48-66.

Subbiah BV \& Asija GL (1956) A rapid procedure for assessment of available nitrogen in rice soils. Current Science 25: 259-260

Tranvan V, Berge O, Ke SN, Balandreau J \&Heulin T (2000) Repeated beneficial effects of rice inoculation with a strain of Burkholderiavietnamiensis on early and late yield components in low fertility sulphate acid soils of Vietnam. Plant \& Soil 218: 273-284

Walkley A \&Black IA (1934) An examination of the Degtjareff method for determination of soil organic matter and a proposed modification of the chromic acid titration method. Soil Science 37: 29-39

Zeigler RS \& Barclay A (2008) The relevance of rice. Rice 1: 3-10
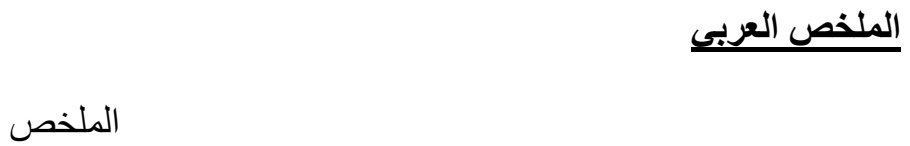